International Journal of Business Management and Economic Review

Vol. 5, No. 01; 2022

ISSN: 2581-4664

\title{
THE ROLE OF LEADERSHIP ON EMPLOYEE DEVELOPMENT AND MOTIVATION TOWARDS INCREASING WORK PRODUCTIVITY OF EMPLOYEES OF THE MENTAL HOSPITAL OF ACEH
}

\author{
Kalena Amala Putri, Muhammad Adam and Teuku Roli Ilhamsyah Putra \\ Management Department, Universitas Syiah Kuala, Indonesia \\ http://doi.org/10.35409/IJBMER.2022.3359
}

\begin{abstract}
This study is to determine and examine the role of leadership in employee development and motivation towards increasing work productivity of Mental Hospital of Aceh (RSJ Aceh) employees. The population was all employees of the RSJ Aceh with the status of civil servants, amounting to 199 people. Samples were taken by the census technique. The research model was analyzed using Structural Equation Modelling. Data were collected using a questionnaire that was circulated through Google form and measured using a Likert scale. The results of descriptive hypothesis testing prove that leadership, employee development, work motivation and work productivity of employees at the RSJ Aceh are not good enough. The results of hypothesis testing directly prove that leadership has a significant effect on employee development, leadership has a significant effect on work motivation, leadership has a significant effect on work productivity, employee development has a significant effect on work productivity, work motivation has a significant effect on work productivity, employee development significantly mediates leadership relationships on work productivity, and work motivation mediates the relationship of leadership to work productivity. These results also prove that employee development and work motivation act as partial mediators. Thus, the model of increasing work productivity in RJS Aceh is a function of improving leadership in influencing employee development and work motivation.
\end{abstract}

Keyword: Leadership, Employee Development, Motivation, and Productivity.

\section{INTRODUCTION}

The role of quality human resources is needed in an organization. The quality of human resources owned by the organization is an important thing for organizations to compete globally. The impact of the development of technology must be able to be balanced with human resources in an organization because no matter how sophisticated the facilities and infrastructure owned by the organization without being supported by quality human resources, it will be difficult for the organization to progress and develop. The quality of work owned by employees can produce quality work which is expected to achieve the goals of the organization. On the other hand, organizational goals are difficult to achieve if employee performance in the organization is poor.

Employees are the basic capital of the organization. Therefore, organizations must be able to increase the work productivity of their employees. The same thing applies to the Aceh Mental Hospital (RSJ Aceh), located in Aceh Province, Indonesia, which is an Indonesian government institution engaged in mental health services for the community.

The study at the RSJ Aceh is interesting because this hospital has a significant role in 


\section{International Journal of Business Management and Economic Review}

Vol. 5, No. 01; 2022

ISSN: 2581-4664

maintaining the psychological life of the community, especially around the province of Aceh. Therefore, a leadership role is needed that can motivate employees so that the performance of employees who have just joined can achieve the goals of the organization. Achievement of performance targets of the RSJ Aceh is measured by 7 (seven) indicators, namely (1) Number of patients with mental disorders who are treated and not neglected, (2) Number of outpatient visits (3) Percentage of patients who are readmission in less than one month, (4) Community Satisfaction Index, (5) Cost Recovery Rate (CRR), Percentage of RSJ ability to cover operational costs with income, (6) Number of shackled patients receiving rehabilitation at RSJ Aceh, and (7) Number of Residents receiving Drug rehabilitation services (drug abuse).

From the results of the assessment of the performance indicators of the RSJ Aceh for the last 3 years, it is known that the community satisfaction index and CRR have fluctuating values and have never reached the predetermined target. This happens inseparable from the work productivity produced by employees at the RSJ Aceh. The low work productivity produced by these employees cannot be separated from the motivational role that each employee has, where employees are not fully motivated to work to excel in the future, the work targets given do not make them more motivated to work, then employees are still less than optimal in completing work so that there are several errors due to negligence, association with other friends who have the same job does not make them more motivated to work as well as in completing work, employees prefer to work individually, not oriented to teamwork spirit and the low desire of employees to work together. master the job.

Another factor that causes low employee productivity is employee development. the development of the RSJ Aceh staff is still not going well, this can be reflected in the education and training provided by the RSJ Aceh to its employees not yet good enough to help employees in supporting their careers, the skills development provided by the RSJ Aceh to their employees has not been able to optimally improve employee careers, the readiness of the RSJ Aceh in providing job descriptions to increase employee work experience has not gone well and technology skills training by RSJ to employees every year is still low and has not fully been able to help better employee performance.

To be able to improve all these things is very dependent on leadership. A reliable leader can always know the problems that are happening in his work environment and will be able to solve all the problems that occur with various innovative solutions. However, this has not been described in the RSJ Aceh environment. Many parties assume that the leadership at the Aceh RSJ is still not going well as expected by the employees. This can be reflected in the leadership's ability to make decisions that are still low, the leadership of the Aceh RSJ has not been fully able to motivate employees to work, the task orders given are sometimes still unclear and cause multiple interpretations by employees, the leadership is not able to control employees to work better, responsibility the responsibility for the work is still not optimal and sometimes the leader is still unable to control emotions.

The problems described above make it difficult for employees to achieve optimal work productivity. This is because work motivation and employee development are still not running optimally. So in this case a leadership role is needed that understands the needs of its employees. To achieve the expected performance productivity, leaders need to know the abilities of each employee and the right way to develop employee abilities.

\section{LITERATURE STUDY}


International Journal of Business Management and Economic Review

Vol. 5, No. 01; 2022

ISSN: 2581-4664

\section{Employee Work Productivity}

Productivity for employees is very important because the work done by employees is very helpful in the growth of the organization. If the organization grows and develops then profits will increase so management will not only be happier but will hire more people and give raises to those who do a good job and increased profits for them.

(Mathis \& Jackson, 2019) defines productivity as a measurement of the quantity and quality of workers. (Greenberg \& Baron, 2018) revealed that productivity is the ratio between the totality of expenditure divided by the totality of income in a certain period. (Daft, 2010) emphasizes that increasing employee productivity means making workers produce more output in the same period. Daft added that organizations can increase employee productivity by providing the means for existing employees to do more, such as by acquiring more efficient technology, by improving work processes, or by training employees to work more efficiently.

From some of the explanations of the experts above, it can be concluded that productivity is a driving force to achieve better quality so that it can improve the welfare of the community by involving human resources in their skills and abilities, technology, and other resources to process existing resources to improve national development. and accelerate the pace of economic growth. Many factors affect work productivity as expressed by (Kasmir, 2016) namely ability and expertise, knowledge, work design, personality, work motivation, leadership, leadership style, organizational culture, job satisfaction, work environment, commitment loyalty, work discipline, and work involvement. Other opinions expressed by (Nitisemito, 2015) mentions the factors that affect work productivity are training and development, mental and physical abilities of employees, the relationship between superiors and subordinates.

\section{Work Motivation}

(Robbins \& Judge, 2017) states that motivation is the desire to do something and determines the ability to act to satisfy individual needs. Work motivation or work motive is a reflection of personal attitudes and attitudes towards group work and collaboration. As the attitude towards each employee, motivation is also more or less influenced by factors on the part of the leader, especially by the wisdom of the leader (Rawung, 2013). Motivation can be interpreted as a driving force that allows people to continue their driving force or activities that move them in the process of realizing their activities (Hilal, 2017).

Although employee motivation is a complex issue, it is not difficult for a manager who knows the employee very well. A different motivational program should be implemented for each employee. Because the needs, levels of satisfaction, psychological conditions, socio-cultural backgrounds of people are different (Sekhar, Patwardhan, \& Singh, 2013). Motivation is an attempt to encourage someone to be able to act in motivational ways that refer to the cause of the emergence of action.

\section{Employee Development}

Human resource development is an effort made by the organization to improve the quality of human resources through several established programs such as conducting employee training, periodic education, and capacity development. (Gomes, 2003) states that human resource development is a process of planning education, training, and manpower management to achieve 


\section{International Journal of Business Management and Economic Review}

Vol. 5, No. 01; 2022

ISSN: 2581-4664

an optimal result for the organization where this process is carried out by the organization. Development has the definition of an effort made to improve human abilities in several ways. according to (Byars \& Rue, 2006), Career development is an organizational effort to develop and enrich its human resources by aligning their needs with the needs of the organization. Development, referring to staffing and staffing issues, is a long-term educational process that utilizes a systematic and organized procedure in which managerial personnel learns conceptual and theoretical knowledge for a general-purpose (Sikula, 2011).

From some of the opinions above, it can be concluded that development has the meaning of an effort and obligation for every member in an organization or organization to improve every competency possessed. This development is needed to meet the needs of the organization in having good quality employee resources. Employee or HR development activities are facilitated by the organization to improve employees so that they have the knowledge, skills, and attitudes of the employee.

\section{Leadership}

Leadership is conceptually defined as the ability to influence others to understand and agree with what other people's judgments/subordinates do regarding emotional control, problem-solving skills, communication skills, and how to motivate others/subordinates (Rawung, 2013). Sources of influence can be formal and informal. Formal influences such as the provision of managerial rankings in a group. This is because the management position is at the same level as the formally appointed level of authority, the manager can act as a leader and carry out leadership functions solely because of his position in the group. But not all managers are called leaders, nor are all leaders called managers. Just because a group gives formal rights to a position as a manager is not a guarantee that the manager can lead effectively and efficiently. (Robbins \& Judge, 2017) says that leaders can emerge in a group through formal appointments.

(Luthans, 2013) explains that leadership is a group of processes, personality, fulfillment, behavior, authority, achievement of goals in a determined manner, interaction, differences in roles in groups, initiation of structure, and a combination of two or more of these things. (Krasnof, 2015) explains the three ideas that are emphasized in leadership theory, these ideas are built together or separately, namely: (1) rationality, behavior and personality of the leader; (2) rationality, behavior and personality of group members; and (3) factors related to task execution, organizational climate and culture.

\section{Research paradigm}

Based on the discussion of the problems and research literature, the researcher formulates the research paradigm and hypotheses as follows. 
International Journal of Business Management and Economic Review

Vol. 5, No. 01; 2022

ISSN: 2581-4664

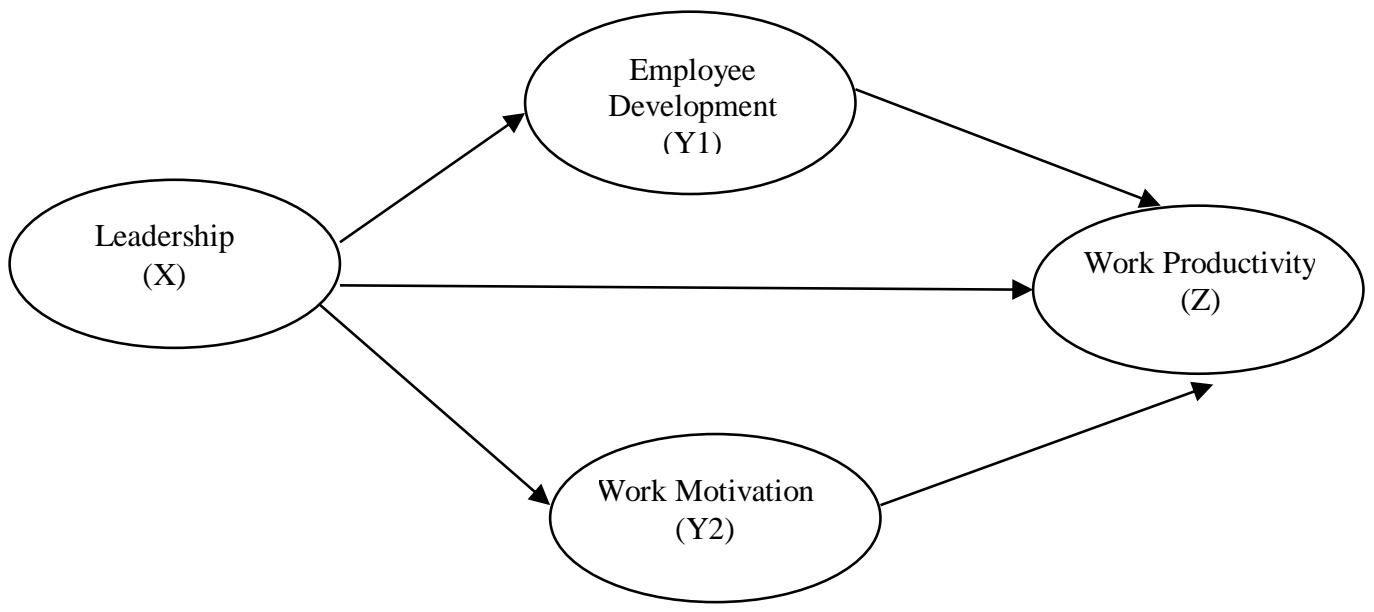

Figure 1. Research Framework

\section{Descriptive Hypothesis}

H1: Leadership, Employee Development, Work Motivation, and Employee Productivity Haven't Run Well

\section{Verification Hypothesis}

H2: Leadership affects Employee Development

H3: Leadership affects work motivation

H4: Leadership affects Work Productivity

H5: Employee Development affects Work Productivity

H6: Work Motivation affects Work Productivity

H7: Leadership affects Work Productivity through Employee Development

H8: Leadership affects Work Productivity through Work Motivation

\section{RESEARCH METHOD}

This research was conducted at the RSJ Aceh located in Province, Indonesia. The objects were leadership, employee development, and employee productivity. The population taken was all employees of the RSJ Aceh with the status of civil servants, totaling 199 people. The sample was selected by the census technique. The use of this technique refers to the theory of (Hair, Hult, Ringle, \& Sarstedt, 2016) wherein his book he states that a study uses the maximum likelihood, the ideal sample is between 100 to 200. Furthermore, the data is collected by distributing questionnaires online using the google form facility. Data was measured using a Likert scale. The independent variable was leadership, the intervening variables were an employee development and work motivation, and the dependent variable was work productivity. The measurement of variables in this study uses the following indicators:

a. Work Productivity used indicators as stated in PP No 30/2019, namely (1) service orientation, (2) commitment, (3) work initiative, (4) cooperation, and (5) leadership. 
International Journal of Business Management and Economic Review

Vol. 5, No. 01; 2022

ISSN: 2581-4664

b. Employee development used indicators revealed by (Chalofsky, Rocco, \& Morris, 2014) namely (1) education, (2) skills, (3) work experience, (4) technological ability.

c. Work motivation with measurement indicators as expressed by (Robbins \& Judge, 2017) namely (1) the need for achievement, (2) work targets, (3) responsibility, (4) the need to expand relationships, (5) communication, (6) friendship, (7) the need to master a job.

d. Leadership used measurement indicators revealed by (Panjaitan \& Prasetya, 2017) namely: (1) exemplary, (2) authority, (3) skills, (4) information delivery, (5) decision making.

The descriptive hypothesis is answered through the average score analysis, and the verification hypothesis/causality relationship is tested through Structural Equation Modelling (SEM). Mathematically the causality relationship between constructs can be stated as follows:

$\eta_{1}=\gamma 1.1 \xi 1+\gamma 1.2 \xi 2+\gamma 1.3 \xi 3+\zeta 1$

$\eta_{2}=\gamma 2.1 \xi 1+\gamma 2.2 \xi 2+\gamma 2.3 \xi 3+\beta 21 \eta_{1}+\zeta 2$

or

Employee Development $\quad=\gamma 1.1$ Leadership $+\zeta 1$

Work Motivation $\quad=\gamma 1.2$ Leadership $+\zeta 1$

Work Productivity $=\gamma 2.1$ Leadership $+\beta 2.1$ Employee Development $+\beta 2.2$ Work Motivation $+\zeta 2$

\section{RESULTS AND DISCUSSION}

Descriptive Hypothesis Testing

From the results of collecting data on respondents' perceptions, it can be seen in table 1 below

Table 1. Respondents' Perceptions of Variables

\begin{tabular}{|c|c|c|c|c|}
\hline No & Variable & Average & $\begin{array}{c}\text { Cut } \\
\text { off }\end{array}$ & Information \\
\hline 1 & Work Productivity (Z) & 3.40 & & $\begin{array}{c}\text { Not Good } \\
\text { Enough }\end{array}$ \\
\hline 2 & Employee Development (Y1) & 3.34 & & $\begin{array}{c}\text { Not Good } \\
\text { Enough }\end{array}$ \\
\hline 3 & Work Motivation (Y2) & 3.42 & \multirow{2}{*}{3.41} & Good \\
\cline { 1 - 2 } \cline { 5 - 5 } & Leadership (X) & 3.36 & & $\begin{array}{c}\text { Not Good } \\
\text { Enough }\end{array}$ \\
\hline 4 & Average & $\mathbf{3 . 3 8}$ & & $\begin{array}{c}\text { Not Good } \\
\text { Enough }\end{array}$ \\
\hline
\end{tabular}

Source: Processed data (2021)

Based on the data in table 1, it can be seen that respondents' perceptions of all variables are not good. of the four research variables, only the work motivation variable has a value of 3.42> 3.41 , while the other variables show a number less than 3.41 . Overall the average value is 3.38 . So it can be concluded that it is true that all the variables in this study, namely leadership, employee development, work motivation, and employee work productivity have not gone well. Thus 
International Journal of Business Management and Economic Review

Vol. 5, No. 01; 2022

ISSN: 2581-4664

rejecting $\mathrm{H} 0$ and accepting $\mathrm{H} 1$.

\section{Direct Hypothesis Testing}

The analysis of the structural model that explains the test of the influence between variables is presented in the following path diagram:

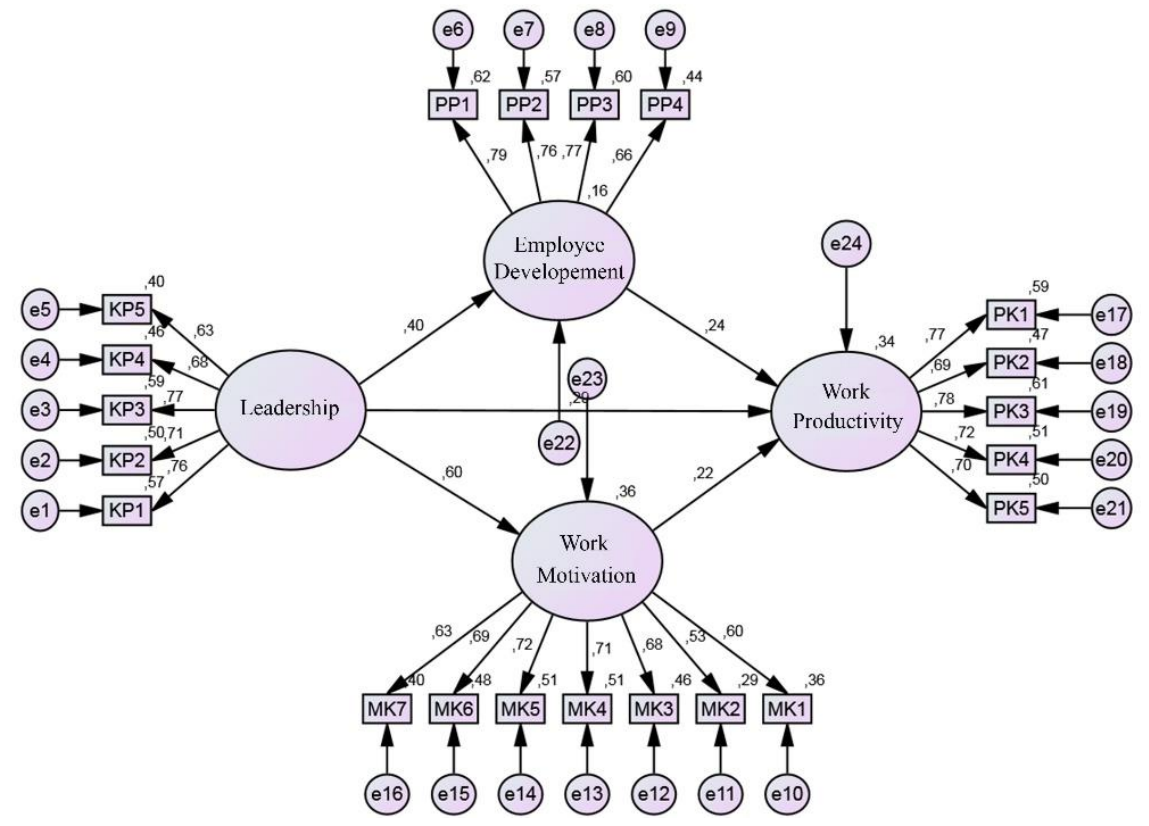

Figure 2. Hypothesis Test Results

The results of testing the full model for hypothesis testing after going through the fulfillment of SEM assumptions are more clearly contained in the following table:

Table 2. Hypothesis Testing Results

\begin{tabular}{|l|l|l|c|c|c|c|c|}
\hline \multirow{2}{*}{ Endogenous } & & \multicolumn{1}{|c|}{ Exogenous } & \multicolumn{2}{c|}{ Estimate } & \multirow{2}{*}{ S.E. } & C.R. & P \\
\cline { 4 - 5 } & & & Unstandard & Standard & \\
\hline $\begin{array}{l}\text { Employee } \\
\text { Development }\end{array}$ & $<---$ & Leadership & 0.387 & 0.402 & 0.083 & 4.667 & $* * *$ \\
\hline $\begin{array}{l}\text { Work } \\
\text { Motivation }\end{array}$ & $<---$ & Leadership & 0.430 & 0.603 & 0.072 & 5.952 & $* * *$ \\
\hline $\begin{array}{l}\text { Work } \\
\text { Productivity }\end{array}$ & $<---$ & $\begin{array}{l}\text { Employee } \\
\text { Developement }\end{array}$ & 0.262 & 0.237 & 0.092 & 2.838 & 0.005 \\
\hline $\begin{array}{l}\text { Work } \\
\text { Productivity }\end{array}$ & $<---$ & Work Motivation & 0.325 & 0.217 & 0.151 & 2.150 & 0.032 \\
\hline $\begin{array}{l}\text { Work } \\
\text { Productivity }\end{array}$ & $<---$ & Leadership & 0.308 & 0.288 & 0.116 & 2.658 & 0.008 \\
\hline
\end{tabular}

Source: Primary Data, 2020 (processed) 
International Journal of Business Management and Economic Review

Vol. 5, No. 01; 2022

ISSN: 2581-4664

From the results of testing the direct influence in the table above, it can be seen that:

1. H2: Leadership affects Employee Development

The influence of leadership on employee development has a C.R value of 4.667 or $>1.95$ and a probability value of $* * *$ or 0.000 or $<0.05$. So it can be concluded that leadership has a direct and significant effect on employee development or in other words this hypothesis accepts $\mathrm{Ha}$ and rejects $\mathrm{H} 0$.

This result is in line with the study of (Hijriah, 2016) and (Onyeonoro \& Okechukw, 2014) which reveals that there is a significant influence of leadership that increases the utilization of human resources and that the behavior of the leader has a significant effect on the employee productivity index that leads to the organization.

The magnitude of the influence of leadership on employee development is seen from the standard estimate value of 0.402 . This means that every $1 \%$ increase in leadership value, will increase employee development by $0.402 \%$. These results explain that leadership is a very important element in developing human resources in organizations. Employees will be more developed if there is concern from leaders to provide their career development through better education and training. Attention and a good leadership process will be very helpful in supporting employee careers.

2. H3: Leadership affects work motivation

The influence of leadership on work motivation has a C.R value of 5.952 or $>1.95$ and a probability value of $* * *$ or 0.000 or $<0.05$. So it can be concluded that leadership has a direct and significant effect on work motivation or in other words this hypothesis accepts $\mathrm{Ha}$ and rejects $\mathrm{H} 0$.

This result is following the study of (Alghazo \& Meshal, 2016); (Akanpaadgi, Valogo, \& Akaligang, 2014) (Rawung, 2013); and (Gerdenitsch et al., 2020). (Apak \& Gümüş, 2015) which reveals leadership qualities can increase employee motivation and performance. The magnitude of the influence of leadership on employee motivation is seen from the standard estimate value of 0.603 . This means that every $1 \%$ increase in the value of leadership, will increase employee motivation by $0.603 \%$. These results explain that to foster a sense of motivation to work for employees, it is very necessary to encourage external (extrinsic) employees, namely the role of leaders to generate motivation and enthusiasm for employees to achieve the desired goals.

3. H4: Leadership Affects Work Productivity

The influence of leadership on work productivity has a C.R value of 2.658 or $>1.95$ and a probability value of 0.008 or $<0.05$. So it can be concluded that leadership has a direct and significant effect on work productivity or in other words this hypothesis accepts $\mathrm{Ha}$ and rejects $\mathrm{H} 0$.

This result is in line with the study of (Harimisa, 2013); (Onyeonoro \& Okechukw, 2014); (Badrani, Madya, \& Meriam, 2015); (Gerdenitsch et al., 2020); and (Tohidi, 2011) which reveals good leadership will significantly create employee productivity. The magnitude of the influence of leadership on employee work productivity is seen from the standard estimate value of 0.288 . This means that every $1 \%$ increase in the value of leadership, will increase employee productivity by $0.288 \%$. These results provide the implementation that leadership 
Vol. 5, No. 01; 2022

ISSN: 2581-4664

is very influential on employee performance. The leadership style adopted can create good relationships with employees and high work motivation which produces good final results following the vision and mission of the organization.

4. H5: Employee Development Affects Work Productivity

The effect of development on work productivity has a C.R value of 2.838 or $>1.95$ and a probability value of 0.005 or $<0.05$. So it can be concluded that employee development has a direct and significant effect on work productivity or in other words this hypothesis accepts $\mathrm{Ha}$ and rejects $\mathrm{H} 0$.

These results support the study of (Onyeonoro \& Okechukw, 2014) and (Badrani et al., 2015) which reveals the development of good human resources by taking into account the needs of the organization will create high work productivity among organizational employees. Employee development can lead to better employee performance (Abogsesa \& Kaushik, 2018). The magnitude of the influence of employee development on work productivity is seen from the standard estimate value of 0.237 . This means that every $1 \%$ increase in the value of employee development, will increase employee work productivity by $0.237 \%$. These results provide an understanding that human resource development is closely related to organizational efforts in improving the quality of employees supported by the flexibility of leaders in achieving organizational goals. Employees who get good training and development will find it easier to work and achieve organizational goals.

5. H6: Work Motivation Affects Work Productivity

The effect of motivation on work productivity has a C.R value of 2.150 or $>1.95$ and a probability value of 0.032 or $<0.05$. So it can be concluded that work motivation has a direct and significant effect on work productivity or in other words this hypothesis accepts $\mathrm{Ha}$ and rejects $\mathrm{H} 0$.

This result is similar to the study of (Harimisa, 2013); (Alghazo \& Meshal, 2016); (Idris, Putra, Djalil, \& Chandra, 2017) dan (Malonda, 2013) which reveals that work motivation has a positive and significant impact on employee work productivity. The magnitude of the influence of motivation on work productivity is seen from the standard estimate value of 0.217 . This means that every $1 \%$ increase in the value of employee motivation, will increase employee work productivity by $0.217 \%$. These results provide an understanding that employees who have high motivation at work will produce better work productivity. Motivation can arise through oneself or from the encouragement of others in the organizational environment. So all elements in the organization are factors that can create employee work motivation as an opinion of (Lunenburg, 2011) that this motivational strategy is used by many organizations as a way to demonstrate individual hard work at work and offer an average to measure productivity

\section{Indirect Hypothesis}

6. H7: Leadership affects Work Productivity through Employee Development

To find out briefly the results of hypothesis testing can be seen in the results of the mediation effect analysis using the Sobel test concept as follows: 
International Journal of Business Management and Economic Review

Vol. 5, No. 01; 2022

ISSN: 2581-4664

\begin{tabular}{|c|c|c|c|c|}
\hline Input: & & Test statistic: & Std. Error: & $p$-value: \\
\hline 0.387 & Sobel test: & 2.43036266 & 0.0417197 & 0.01508372 \\
\hline$b 0.262$ & Aroian test: & 2.39064873 & 0.04241276 & 0.01681864 \\
\hline$s_{3} 0.083$ & Goodman test: & 2.47212392 & 0.04101493 & 0.01343129 \\
\hline$s_{b} 0.092$ & Reset all & \multicolumn{3}{|c|}{ Calculate } \\
\hline
\end{tabular}

Figure 3 Result of Test for H7

The results of the Sobel Test calculation where the p-value of 0.015 is less than 0.05 . Based on the results of significant calculations for path $C^{\prime}$ using the Sobel test, the significant values for all paths (A, B, C, and $\left.\mathrm{C}^{\prime}\right)$ can be seen in Figure 4 below:

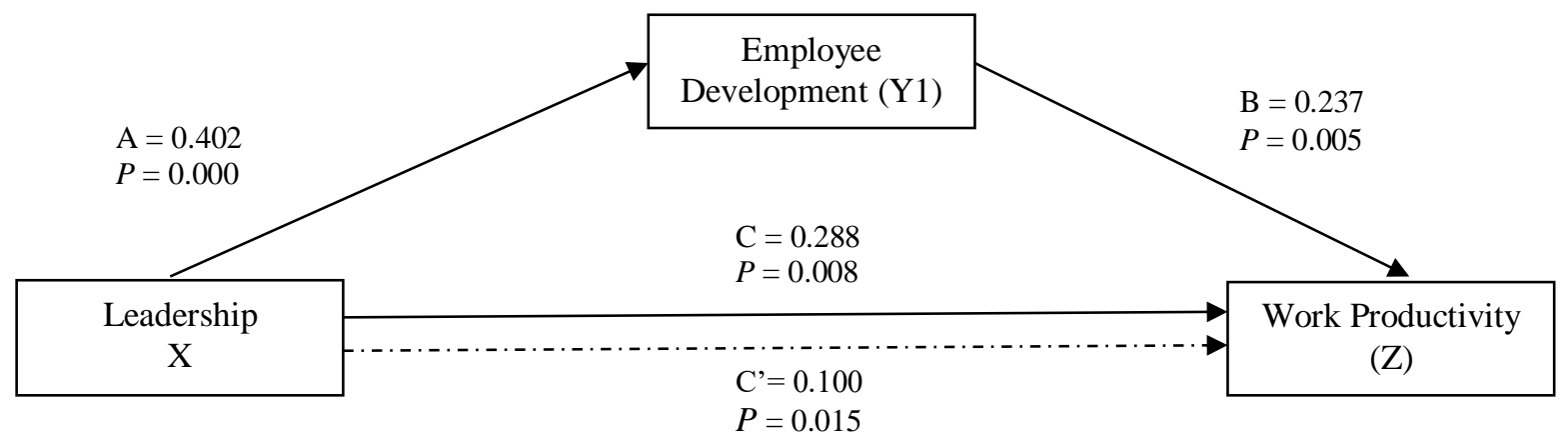

Figure 4. Result of H7 Model

\section{Information:}

$\mathrm{A}=$ Coefficient of leadership influence on employee development

$\mathrm{B}=$ Coefficient of influence of employee development on work productivity

$\mathrm{C}=$ Coefficient of leadership influence on work productivity

$\mathrm{C}^{\prime}=$ Coefficient of mediating effect of employee development on leadership relationships on work productivity

$\mathrm{P}=$ Probability or significance value

Figure 4 can be explained that the coefficients of path A, paths B and C, are significant and the significant value of path $\mathrm{c}^{\prime}$ is also significant. The results of this study indicate that the variable of employee development is expressed as a partial mediation variable (Partial Mediation). The results of this study indicate that accepting the hypothesis that employee development mediates the relationship between leadership and employee productivity is 0.10 . This means that the role of employee development in mediating the influence of leadership on employee work productivity is $0.10 \%$.

These results support the study by (Hijriah, 2016) which reveals that leadership has a significant effect on HR development. (Onyeonoro \& Okechukw, 2014) continued to reveal that there is a significant influence of leadership style which should increase the utilization of human resources and that the behavior of the leader has a significant effect on the employee productivity index that leads to the organization. (Badrani et al., 2015) concluded that the 
International Journal of Business Management and Economic Review

Vol. 5, No. 01; 2022

ISSN: 2581-4664

significant influence of shared leadership on human resource management and organizational behavior. The results also show that organizational behavior and human resource management positively affect job performance.

7. $\mathrm{H} 8=$ Leadership influences work productivity through work motivation

To find out briefly the results of hypothesis testing can be seen in the results of the mediation effect analysis using the Sobel test concept as follows:

\begin{tabular}{|c|c|c|c|c|}
\hline Input: & & Test statistic: & Std. Error: & $p$-value: \\
\hline$a .430$ & Sobel test: & 2.57053599 & 0.04382744 & 0.01015413 \\
\hline $\begin{array}{ll}b \quad 0.262 \\
\end{array}$ & Aroian test: & 2.54167052 & 0.04432518 & 0.01103241 \\
\hline $\begin{array}{ll}s_{\mathrm{a}} & 0.072\end{array}$ & Goodman test: & 2.6004078 & 0.04332397 & 0.0093113 \\
\hline \begin{tabular}{l|l}
$s_{\mathrm{b}}$ & 0.092
\end{tabular} & Reset all & \multicolumn{3}{|c|}{ Calculate } \\
\hline
\end{tabular}

Figure 5. Result of Test for $\mathrm{H} 8$

The results of the Sobel Test calculation where the p-value of 0.010 is less than 0.05. Based on the results of significant calculations for path $C^{\prime}$ using the Sobel test, the significant values for all paths (A, B, C and $\left.C^{\prime}\right)$ can be seen in Figure 6 below:

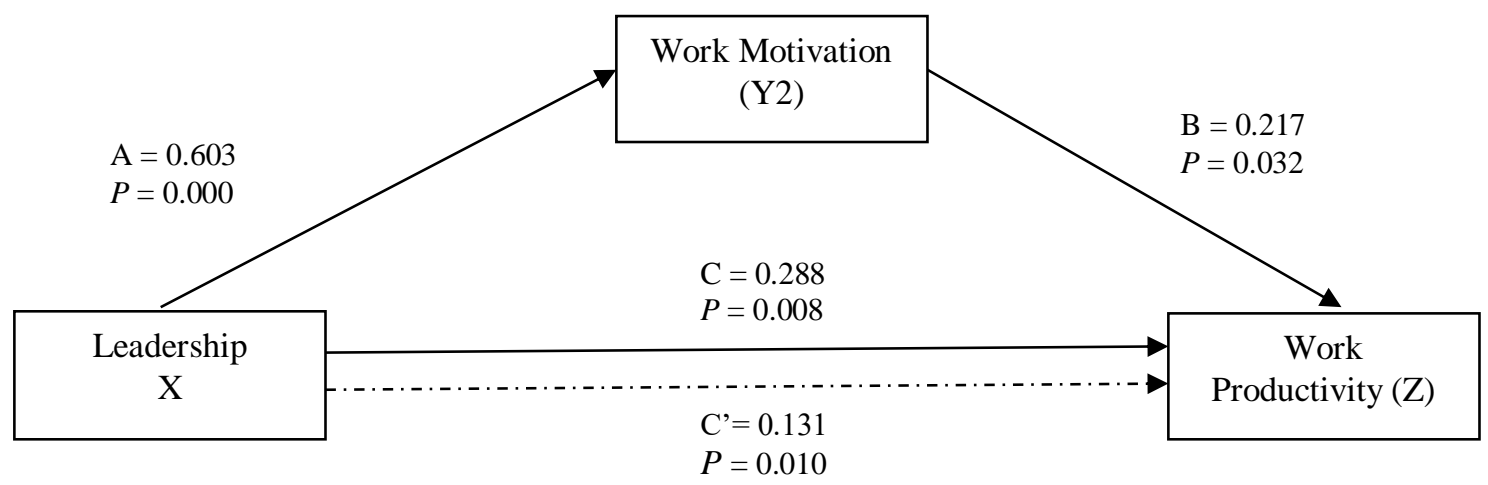

Figure 6. Result of H8 Model

\section{Information:}

$\mathrm{A}=$ Coefficient of leadership influence on work motivation

$\mathrm{B}=$ Coefficient of work motivation influence on work productivity

$\mathrm{C}=$ Coefficient of leadership influence on work productivity

$\mathrm{C}^{\prime}=$ The coefficient of work motivation mediating effect on the leadership relationship on work productivity

$\mathrm{P}=$ Probability or significance value

Figure 6 can be explained that the coefficients of path A, paths B and C, are significant and the significant value of path $\mathrm{c}^{\prime}$ is also significant. The results of this study indicate that the variable of work motivation is expressed as a partial mediation variable (Partial Mediation). The results of this study indicate that accepting the hypothesis that work motivation mediates 


\section{International Journal of Business Management and Economic Review}

Vol. 5, No. 01; 2022

ISSN: 2581-4664

the relationship of leadership to employee work productivity is $0.131 \%$.

These results support research by (Rawung, 2013); (Alghazo \& Meshal, 2016); (Apak \& Gümüş, 2015); and Malonda, (2013) that leadership greatly affects employee motivation. Work motivation will determine employee performance or work productivity. In other words, leadership will indirectly affect employee work productivity through the high and low work motivation of the employees themselves.

\section{CONCLUSION}

Based on the results of the descriptive hypothesis testing, it is known that leadership, employee development, work motivation, and work productivity of employees at the RSJ Aceh are not good. Based on the results of direct hypothesis testing, it is known that leadership has a significant effect on employee development at RSJ Aceh by $0.402 \%$. Furthermore, the results of direct hypothesis testing are also known that leadership has a significant effect on work motivation at RSJ Aceh by $0.603 \%$. Then it is also known that leadership has a significant effect on work productivity at RSJ Aceh $0.288 \%$.

The results of direct hypothesis testing also found that employee development had a significant effect on work productivity at RSJ Aceh by $0.237 \%$. Furthermore, the results of direct hypothesis testing also found that work motivation had a significant effect on work productivity at RSJ Aceh by $0.217 \%$. Furthermore, the results of indirect hypothesis testing or mediation through the proof of the Sobel test show that employee development mediates the relationship between leadership and work productivity by $0.10 \%$. The results of the hypothesis testing of the mediation effect are also known that work motivation mediates the relationship of leadership to work productivity by $0.10 \%$. These results also prove that employee development and work motivation act as partial mediators. Thus, the model of increasing work productivity in RJS Aceh is a function of improving leadership in influencing employee development and work motivation. For model development, further researchers can do this by adding new variables such as human capital management and talent management.

Several practical recommendations, especially for the object of research, namely the RSJ Aceh, resulted from this study. To increase work productivity, the leadership of the RSJ Aceh needs to provide better guidance and direction to employees on how to make employees work following the Employee Performance Targets that have been set by the government. Then employees must be allowed to express opinions and ideas or new ways of completing tasks. Leaders must be able to motivate employees to work better and earnestly by providing direct direction and encouraging lazy employees to be more diligent and providing strict sanctions for employees who are not disciplined in their work, it is also required that colleagues must provide mutual support to each other in their work. finish the job.

Leaders must always provide employee development by providing education and training both formal and non-formal that are better and on target for employees who deserve it so that they can increase the knowledge and skills of employees at work. The provision of additional tasks to increase employee insight also needs to be considered. The leadership of the RSJ Aceh must be able to be an example for their subordinates, the leader must be able to influence his subordinates to work harder, then the leader must master the situation and conditions within the organization and have creative ideas in solving problems, the delivery of work information must be clearer and firmer and the process decision making must be more effective 
International Journal of Business Management and Economic Review

Vol. 5, No. 01; 2022

ISSN: 2581-4664

\section{REFERENCES}

Abogsesa, A. S., \& Kaushik, G. (2018). Impact of Training and Development on Employee Performance. International Journal of Civic Engagement and Social Change, 4(3), 53-68. https://doi.org/10.4018/ijcesc.2017070104

Akanpaadgi, E., Valogo, M., \& Akaligang, C. (2014). An Assessment of the Effects of Leadership on the Motivation of Employees towards the Achievement of Organizational Goals : A Case Study of the Hospitality Industry in the Bolgatanga Municipality. European Journal of Business and Management, 6(24), 9.

Alghazo, A. M., \& Meshal, A.-A. (2016). The Impact of Leadership Style on Employee' s Motivation. International Journal of Economics and Business Administration, 5(1), 37-44.

Apak, S., \& Gümüş, S. (2015). A Research about the Effect of the Leadership Qualities of Public Administrators on the Motivation of the Employees. Procedia - Social and Behavioral Sciences, 210, 368-377. https://doi.org/10.1016/j.sbspro.2015.11.384

Badrani, M. R. A. K., Madya, \& Meriam, S. (2015). Impact of shared leadership on human resource management, organizational behavior and job performance at Almadar Aljadeed Company Tripoli- Libya. International Journal of Applied Research, 1(13), 720-725.

Byars, L. L., \& Rue, L. W. (2006). Human Resource Management (8th, revised ed.). New York: MCGraw-Hill, Irwin.

Chalofsky, N. E., Rocco, T. S., \& Morris, M. L. (2014). Handbook of Human Resource Development. https://doi.org/10.1002/9781118839881

Daft, R. L. (2010). New Era Of Management (9th ed.). Jakarta: Salemba Empat.

Gerdenitsch, C., Sellitsch, D., Besser, M., Burger, S., Stegmann, C., Tscheligi, M., \& Kriglstein, S. (2020). Work gamification: Effects on enjoyment, productivity and the role of leadership. Electronic Commerce Research and Applications, 43(May 2019). https://doi.org/10.1016/j.elerap.2020.100994

Gomes, F. C. (2003). Manajemen sumber daya manusia. Yogyakarta: Andi.

Greenberg, J., \& Baron, R. A. (2018). Behavior in Organizations: Understanding and Managing the Human Side of Work (Ed. 8). New Jersey: Prentice Hall.

Hair, J. F., Hult, G. T. M., Ringle, C., \& Sarstedt, M. (2016). A Primer on Partial Least Squares Structural Equation Modeling (PLS-SEM) (2nd ed.). Thousand Oaks: Sage Publications, Inc.

Harimisa, M. E. (2013). Kepemimpinan dan Motivasi Kerja Pengaruhnya terhadap Produktivitas Kerja Pegawai di Kantor Camat Sario Kota Manado. EMBA, 53(9), 1689-1699. https://doi.org/10.1017/CBO9781107415324.004

Hijriah. (2016). Pengaruh Kepemimpinan Terhadap Pengembangan Sumber Daya Manusia Di Lingkup Sekretariat Dewan Perwakilan Rakyat Daerah Kabupaten Mamuju Utara. Katalogis, 4(5), 37-50.

Hilal, C. (2017). The Relationship Between Employee Motivation Leadership. Balkan and Near Eastern Journal of Social Sciences, 3(3), 97-102.

Idris, S., Putra, T. R. I., Djalil, P. M. A., \& Chandra, M. D. R. (2017). The Analysis of Effectiveness of Education, Training and Motivation on Work Productivity and Its Impact on the Performance of Civil Service of Personel, Education and Training Agency,(BKPP), The Province of Aceh, Indonesia. Journal of Resources Development and Management, 29, 32 37. Retrieved from https://iiste.org/Journals/index.php/JRDM/issue/view/2887

Kasmir. (2016). Manajemen Sumber Daya Manusia: Teori Dan Praktik. Jakarta: Rajawali Pers. 


\section{International Journal of Business Management and Economic Review}

Vol. 5, No. 01; 2022

ISSN: 2581-4664

Krasnof, B. (2015). Leadership Qualities of Effective Principals. Northwest Comprehensive Center, $10 . \quad$ Retrieved from https://compcenternetwork.org/sites/default/files/archive/research-brief-leadership-qualitieseffective-principals.pdf

Lunenburg, F. C. (2011). Self-efficacy in the workplace: Implications for motivation and performance. International Journal of Management, Business, and Administration, 14(1), 16.

Luthans, F. (2013). Organizational Behavior An Evidence-Based Approach (8th ed.). New York: Mc Graw Hill.

Malonda, V. (2013). kepuasan, motivasi kerja, produktivitas kerja. EMBA, 1(3), 969-979.

Mathis, R. L., \& Jackson, J. H. (2019). Human Resource Management: Personnel Human Resource Management (Ed. 15). USA: Harvard Business Review.

Nitisemito, A. S. (2015). Manajemen Personalia. Jakarta: Ghalia Indonesia.

Onyeonoro, \& Okechukw, C. (2014). The Impact of Leadership Style on Effective Human Resources Management and Productivity in Hospitality Organizations. Journal of Technical Education and Management Sciences, 9(2), 106-117.

Panjaitan, P., \& Prasetya, A. (2017). Pengaruh Social Media Terhadap Produktivitas Kerja Generasi Millenial (Studi Pada Karyawan PT. Angkasa Pura I Cabang Bandara Internasional Juanda). Jurnal Administrasi Bisnis, 48(1), 173-180.

Rawung, F. H. (2013). The Effect of Leadership on the Work Motivation of Higher Education Administration Employees (Study at Manado State University). IOSR Journal of Business and Management, 15(1), 28-33. https://doi.org/10.9790/487x-1512833

Robbins, S. P., \& Judge, T. A. (2017). Essential of Organisational Behaviour (14th ed.). New Jersey: Pearson.

Sekhar, C., Patwardhan, M., \& Singh, R. K. (2013). A literature review on motivation. Global Business Perspectives, 1, 471-487. https://doi.org/https://doi.org/10.1007/s40196-013-00281

Sikula, A. A. (2011). Manajemen Sumber Daya Manusia. Bandung: Erlangga.

Tohidi, H. (2011). Teamwork productivity \& effectiveness in an organization base on rewards, leadership, training, goals, wage, size, motivation, measurement and information technology. Procedia Computer Science, 3, 1137-1146. https://doi.org/10.1016/j.procs.2010.12.185 